\title{
A Study on Application of Pickling Sludge in Pavements Tiles
}

\author{
Anuradha Devi ${ }^{1}$, Rajiv Gupta ${ }^{1}$, Anupam Singhal ${ }^{1}$, Sanjay Kumar Verma ${ }^{2}$ \\ ${ }^{1}$ Department of Civil Engineering, Birla Institute of Technology \& Science \\ Pilani, Pin. 333 031, Rajasthan, India \\ er.annu08@gramail.com \\ ${ }^{2}$ Department of Biological Science, Birla Institute of Technology \& Science \\ Pilani, Pin. 333 031, Rajasthan, India
}

\begin{abstract}
Spent pickling liquor disposal is not safe according to US K062 the Environmental Protection Agency (EPA) and Hazardous Waste (Management \&Handling) Rule, 1989. In the normal practice pickling sludge is being disposed off on both sides of roads and railway tracks to fill low-lying areas. This may cause a severe problem of ground water contamination. In the present study, an attempt has been made to examine the potential of utilizing Solidification and stabilization (S/S) pickling sludge in pavement tiles as a substitute to cement to avoid disposal problem. The results of this work showed that the compressive strength of pavement tiles increases by replacing cement with pickling sludge up to $10 \%$. As per US EPA TCLP test, heavy metal $(\mathrm{Fe}, \mathrm{Cr}$, and $\mathrm{Ni})$ concentrations are below detectable limit in the leachate of pavement tiles at 28 days of curing. Thus, sludge-cement pavement tiles can be safely used on the footpath. Reusing pickling sludge as the raw materials of the pavement will not only solve the disposal problem, but also decrease the producing cost of pavement.
\end{abstract}

Keywords: Pickling sludge, Hazardous waste, Waste utilization, Pavement tiles, Compressive strength.

\section{Introduction}

Mild steel comprises of iron-base alloys along with metals such as Chromium, Nickel, and Manganese etc., in negligible quantity. Hence, the consumption of alloying metals utilized for mild steel production is growing steadily. Prior to metal forming and rolling, a salient step for the generation of a non-corrosive and homogeneous surface is pickling (Bralla, 2007). It may be defined as the removal of oxide layers and impurities from the surface of the steel and is carried out by immersion of steel in a combination of strong acids like $\mathrm{HNO}_{3}, \mathrm{HCl}$ etc. with $\mathrm{HF}$ referred to as mixed acid (Galvez et al., 2006). The solution used for the descaling and cleaning of steel containing these strong acids is called pickling liquor. The spent pickling liquor (SPL) depending on composition can be broadly classified into two groups as:

- Solutions from hot-dip galvanizing plant ( $\mathrm{HCl}$ (5-10\%), $\mathrm{Fe}$ (5-15\%) and $\mathrm{Zn}$ ) (Agrawal and Sahu, 2009)

- Solutions from rolling mills ( $\mathrm{HF} \& \mathrm{HNO}_{3}, \mathrm{HF} \& \mathrm{H}_{2} \mathrm{SO}_{4}, \mathrm{H}_{2} \mathrm{O}_{2}, \mathrm{Fe}$ and other metal ions)

The chemical reactions due to pickling process lead to the formation of metal salts and results in significant release of waste products such as metal oxide particles, metal enriched acid solutions and metal containing neutralization sludge (Rogener et al., 2012). Due to the presence of high content of residual acid and metals, spent liquors have been designated as K062 in the in the Environmental Protection Agency (EPA) hazardous waste list of the USA (Bing et al., 2012). The wastes generated during the pickling process can be classified into the following:

- Sludge containing metal oxides generated by the precipitation of metal scale, rust and dust which settles at the bottom

- Sludge containing hydroxides generated during the treatment of the pickling wastewater and spent liquor with lime (Singhal et al., 2007).

Lately emphasis hasbeen laid on the regeneration of spent acid in large industries. Two approaches that have been widely in use can be summarized as either total regeneration of acid and metals by pyro-metallurgical processes or partial regeneration of the acid by diffusion dialysis, retardation, nano-filtration or electro dialysis (Regel-Rosocka, 2010; Baba, 2011). Although these processes significantly reduce the volume of the waste to be discharged, but they demand huge investment and pose environmental risk during transportation (Devi et al., 2014). 
The most common technology used for the treatment of the pickling liquor is neutralized with alkaline additives such as caustic soda, liquid ammonia, quicklime, limestone or slaked lime (Ito, 1998). Neutralization of the pickling liquor leads to sludge production and thereby necessitates its disposal. Methods such as landfills have been put to use for the disposal of such hazardous materials. However, the landfill technique poses problems like continuous demand of land, pollution of soil and ground water due to leaching of heavy metals etc. Hazardous waste is Solidification/Stabilization (S/S) by various types of binders prior to landfill disposal of hazardous waste (Minocha and Verma, 2003; Wang, 2009). The objectives of $\mathrm{S} / \mathrm{S}$ process - (a) chemically react with the free water in the waste to form a dry solid, and (b) makes the contaminants as immobile as possible. The high leach ability of heavy metals in sludge requires proper sludge management, including waste minimization, metal recovery and safe disposal (Vijay and Sihorwala 2003). Reuse of industrial solid waste as a partial replacement of aggregate in construction activities not only saves landfill space but also reduces the demand for extraction of natural raw materials (Ismail and Hashmi, 2008).

Therefore, in the present study an attempt has been trying to examine the potential of utilizing s/s pickling sludge in pavement tiles as a substitute for cement

\section{Materials and procedure}

Pickling liquor procured from mild steel industry. Pickling liquor is being characterized as per the standard methods on Atomic Absorption Spectrometer (AAS) (Standard methods for the examination of water \& wastewater, 20 thed. Washington, DC: APHA, AWWA, WEF, 1998). Pickling liquor is treated with lime (commercial grade) and the pickling sludge produced in this process is used for the study.

\subsection{Characterization of the Pickling Sludge}

The X-ray fluorescent spectroscopy (XRF) analysis was carried out at Aditya Birla Science \& Technology Centre Limited, Mumbai by using WD-XRF (S8 Tiger-Bruker) in accordance with ISO 9516-1:2003.

\subsection{Preparation of cement-concrete pavement tile}

An attempt has been made to make cement concrete pavement tile with a mixture of cement and sludge. The tiles were manufactured in the Maharaja Trading Company situated in Pilani Rajasthan, India. The company manufactures three shapes of pavement tiles for commercial purpose. This industry makes pavement tile with cement, fine aggregate and coarse aggregate using a ratio of 1:2:4. Three different shapes of tiles (Dumbbell, hexagonal and triangular shapes (Figure 1)) were prepared that can be used as footpath tiles and safely immobilize the heavy metals present in the sludge. Table 1 presents the composition of these tiles. The specimens were prepared by adding different proportions of sludge as a substitute to cement with cement to sand to stone grit in the ratio 1:2:4.
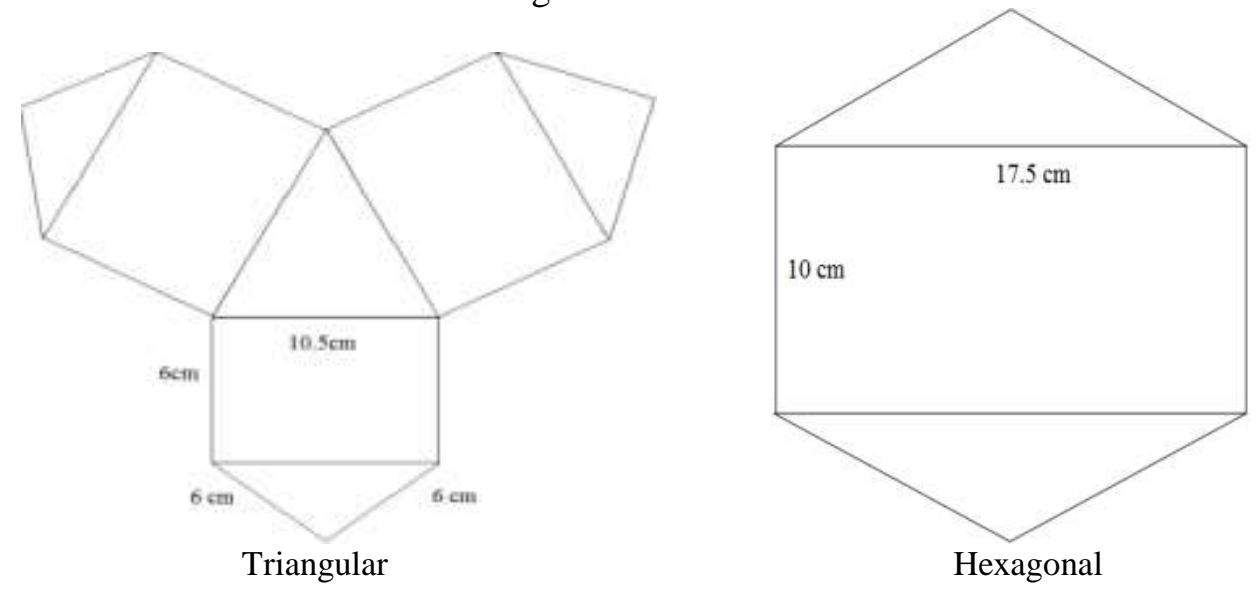


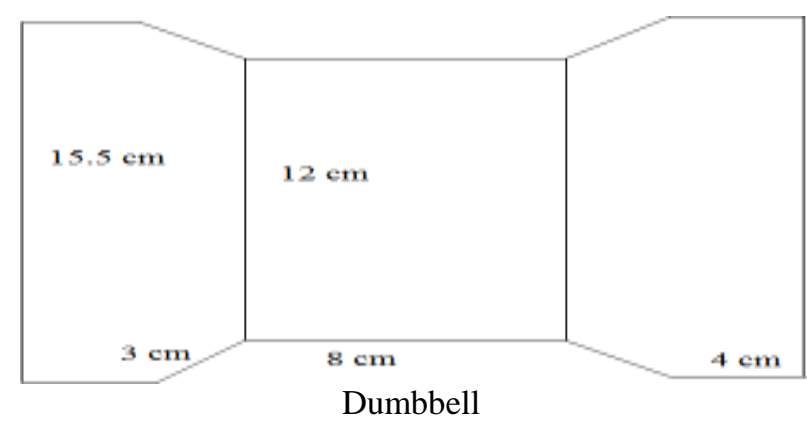

Fig. 1: Different shapes of Tiles.

Table 1: Designation of Tiles.

\begin{tabular}{|c|c|c|c|}
\hline Tiles Code & $\begin{array}{c}\text { Thickness } \\
\text { (in mm) }\end{array}$ & \% of Sludge & Shapes \\
\hline B (Blank) & 60 & - & Dumbbell (D), Hexagonal (H), Triangular (T) \\
\hline C & 60 & 2.5 & Dumbbell (D), Hexagonal (H), Triangular (T) \\
\hline D & 60 & 5 & Dumbbell (D), Hexagonal (H), Triangular (T) \\
\hline E & 60 & 7.5 & Dumbbell (D), Hexagonal (H), Triangular (T) \\
\hline F & 60 & 10 & Dumbbell (D), Hexagonal (H), Triangular (T) \\
\hline
\end{tabular}

\subsection{Cement}

In the study, ordinary Portland cement 43 grade was used.

\subsubsection{Chemical properties of cement}

Chemical properties of the cement were determined as per IS $(4032,1985)$.

\subsection{Fine aggregate (Sand)}

Fine aggregate was analyzed as per IS: 383-1970

\subsection{Coarse aggregate}

Coarse aggregate was used as per IS: $(383,1970)$.

\subsection{Casting of tiles}

All the concrete was mixed in Hand Feed Concrete Mixer. The speed of the mixer was about 25 rpm. All cementsludge concrete cubes were cast in cast iron mould at $27 \pm 2{ }^{\circ} \mathrm{C}$. For compaction of concrete cubes vibrating Table was used. The Vibrating Table was operated by 5 HP motor with speed of $12000 \pm 400 \mathrm{rpm}$. All the concrete cubes were cured with moist gunny bags and after 24 hours all the cubes were dipped in water at the temperature of $27 \pm 2{ }^{\circ} \mathrm{C}$.

\subsection{TCLP test for pavement tiles}

TCLP test (18 hrs) was conducted on the tiles containing pickling sludge as per US EPA standards. After 28 days of curing, a slice of concrete approximately $9.5 \mathrm{~mm}$ thick was cut from the mid-height of the tile. A part of each slice weighing approximately $100 \mathrm{~g}$ was crushed carefully using a hammer so that all particles were $9.5 \mathrm{~mm}$, but the variation of the particle size distribution was not significant. Each crushed concrete sample was treated with an acetic acid solution of $\mathrm{pH} 2.88$ at a liquid-to-solid ratio of $20: 1$ for a period of $18 \mathrm{~h}$ in the bottles. The bottles were shaken at 28-30 rpm in an Orbital shaker at room temperature for $18 \mathrm{~h}$. At the end of the extraction, the leachates were filtered with through a 0.45 $\mathrm{mm}$ membrane filter to remove suspended solids. The $\mathrm{pH}$ of the filtrate was measured and the leachate was analyzed on UV Spectrophotometer for $\mathrm{pH}$ and iron.

\subsection{Compression Testing Machine}


Compressive strength of all the cement-sludge sand mortar cubes was tested by using a Compression Testing Machine (SCHAFF HOUSE, Switzerland and supplied by Alfred J. Amsler \& Co.). The working range of the Compression Testing Machine was 0-200 tones.

\section{Results and Discussions}

\subsection{Characterization of the pickling sludge}

The pickling sludge characterization results are presented in Table 2. The $\mathrm{pH}$ of pickling sludge is 7.5.

Table 2: Pickling sludge characterization.

\begin{tabular}{|l|c|}
\hline Parameters & Concentration (\%) \\
\hline Lime $(\mathrm{CaO})$ & $71.52 \%$ \\
\hline Oxygen $(\mathrm{O})$ & $6.32 \%$ \\
\hline Chloride $(\mathrm{Cl})$ & $6.45 \%$ \\
\hline Magnesia $(\mathrm{MgO})$ & $6.19 \%$ \\
\hline Iron Oxide $\left(\mathrm{Fe}_{2} \mathrm{O}_{3}\right)$ & $6.12 \%$ \\
\hline Silica $\left(\mathrm{SiO}_{2}\right)$ & $1.87 \%$ \\
\hline Alumina $\left(\mathrm{Al}_{2} \mathrm{O}_{3}\right)$ & $0.4 \%$ \\
\hline Loss on Ignition $(\mathrm{LOI})$ at the temperature of $1050^{\circ} \mathrm{C}$ & $11.53 \%$ \\
\hline Bulk Density & $2020 \mathrm{~kg} / \mathrm{m}^{3}$ \\
\hline Moisture content of the sludge & $1.5 \%$ \\
\hline
\end{tabular}

\subsection{Sieve analysis of sludge}

Oven dried sludge samples of $500 \mathrm{~g}$ each had been taken for sieve analysis. Sieve analysis was carried out by using standard procedures. Sieve analysis results are shown in Table 3.

Table 3 shows that more than $50 \%$ of all the sludge have a particle size greater than $178 \mu$ mand below $35 \mu \mathrm{m}$ size these are negligible.

Table 3: Sieve analysis of pickling sludge.

\begin{tabular}{|c|c|}
\hline Sieve size $(\boldsymbol{\mu m})$ & Pickling Sludge $(\boldsymbol{\%}$ retained $)$ \\
\hline 180 & 51.1 \\
\hline 150 & 4.8 \\
\hline 125 & 8.9 \\
\hline 105 & 3.9 \\
\hline 90 & 6.2 \\
\hline 75 & 7.8 \\
\hline 63 & 8.3 \\
\hline 53 & 3.2 \\
\hline 35 & 5.8 \\
\hline
\end{tabular}

\subsection{Chemical Composition and Physical Properties of the Cement}

Ordinary Portland cement 43 grade was used for the study. Chemical and physical properties of the cement are presented in Table 4.

Table 4: Chemical and physical properties of cement.

\begin{tabular}{|c|l|c|}
\hline \multicolumn{2}{|c|}{ Chemical Analysis } \\
\hline S. No. & \multicolumn{1}{|c|}{ Parameter } & Value \\
\hline 1 & Lime $(\mathrm{CaO})$ & $63.5 \%$ \\
\hline 2 & Silica $\left(\mathrm{SiO}_{2}\right)$ & $19.05 \%$ \\
\hline 3 & Alumina $\left(\mathrm{Al}_{2} \mathrm{O}_{3}\right)$ & $4.2 \%$ \\
\hline 4 & Iron Oxide $\left(\mathrm{Fe}_{2} \mathrm{O}_{3}\right)$ & $3.1 \%$ \\
\hline 5 & Magnesia $(\mathrm{MgO})$ & $2.9 \%$ \\
\hline
\end{tabular}




\begin{tabular}{|c|l|c|}
\hline 6 & Sulphur Tri Oxide $\left(\mathrm{SO}_{3}\right)$ & $2.5 \%$ \\
\hline 7 & $\begin{array}{l}\text { Soda and/or Potash } \\
\left(\mathrm{Na}_{2} \mathrm{O}+\mathrm{K}_{2} \mathrm{O}\right)\end{array}$ & $0.9 \%$ \\
\hline 8 & Loss on Ignition Physical Tests & $2.1 \%$ \\
\hline \multicolumn{2}{|c|}{ Phent paste } & $28 \%$ \\
\hline 1 & Consistency of standard cement & $3.5 \mathrm{~mm}$ \\
\hline 2 & Soundness of cement & $125 \mathrm{~min}$ \\
\hline 3 & Initial setting time of cement & $182 \mathrm{~min}$ \\
\hline 4 & Final setting time of cement & $2698 \mathrm{~cm}^{2} / \mathrm{g}$ \\
\hline 5 & Fineness by air permeability & \\
\hline
\end{tabular}

\subsection{Fine Aggregate (Sand) Analysis}

Sieve analysis of the fine aggregate is presented in Table 5.

Table 5: Sieve analysis results of fine aggregate.

\begin{tabular}{|c|c|c|}
\hline IS Sieve Size & \% Retained & \multicolumn{1}{c|}{ Remark } \\
\hline $4.75 \mathrm{~mm}$ & 10.73 & \\
\hline $2.36 \mathrm{~mm}$ & 21.03 & \\
\hline $1.7 \mathrm{~mm}$ & 30.69 & \\
\hline $1.18 \mathrm{~mm}$ & 40.34 & \multirow{4}{*}{ Conforming to grading zone(3) of Table 4.9 of IS: 383-1970 } \\
\hline $600 \mu \mathrm{m}$ & 51.64 & \\
\hline $300 \mu \mathrm{m}$ & 64.36 & \\
\hline $150 \mu \mathrm{m}$ & 79.33 & \\
\hline $90 \mu \mathrm{m}$ & 90.54 & \\
\hline Remaining & 100 & \\
\hline
\end{tabular}

\subsection{Coarse Aggregate Analysis}

Sieve analysis of the coarse aggregate is presented in Table 6.

Table 6: Sieve analysis results of coarse aggregate.

\begin{tabular}{|l|l|l|}
\hline IS Sieve Size & Coarse Aggregate (Percent Passing) & Remarks \\
\hline $20 \mathrm{~mm}$ & 100 & $\begin{array}{l}\text { Special type of coarse aggregate is used for the } \\
\text { production of cement concrete pavement tiles. } \\
\text { Commercial name of the gravel is zero size }\end{array}$ \\
\hline $10 \mathrm{~mm}$ & 100 & \\
\hline
\end{tabular}

\subsection{TCLP test for pavement tiles}

Table 7 shows the Fe leachate concentration of pickling sludge and pavement tiles at 28 days curing. It is clear from the results that $\mathrm{Fe}$ concentration is negligible in leachate. It is due to non-dissolving nature of pickling sludge in acids and S/S (Singhal et al., 2008).

Table 7: TCLP (18h) test results for sludge-concrete mix pavement tiles after 28 days of curing.

\begin{tabular}{|c|c|c|c|c|}
\hline Tiles Code & Thickness $(\mathbf{m m})$ & \% of Sludge & Iron $\mathbf{( m g / l})$ & $\mathbf{p H}$ \\
\hline B (Blank) & 60 & - & BDL $^{*}$ & 5.1 \\
\hline C & 60 & 2.5 & BDL & 5.2 \\
\hline D & 60 & 5 & BDL & 5.1 \\
\hline E & 60 & 7.5 & BDL & 5 \\
\hline F & 60 & 10 & BDL & 5 \\
\hline
\end{tabular}

*BDL-Below detectable limit 


\subsection{Compressive Strength}

The compressive strength after 7 and 28 days is given in Table 8 and Table 9 respectively is average of 5 samples.

Table 8: Compressive Strength of sludge-concrete mix pavement tiles after 7days.

\begin{tabular}{|c|c|c|c|c|c|}
\hline \multirow[b]{2}{*}{ Tiles Code } & \multirow[b]{2}{*}{$\begin{array}{c}\text { Thickness } \\
\text { (mm) }\end{array}$} & \multirow[b]{2}{*}{$\begin{array}{c}\% \text { of } \\
\text { Sludge }\end{array}$} & \multicolumn{3}{|c|}{ Compressive Strength after 7days } \\
\hline & & & $\begin{array}{l}\text { Dumbbell } \\
\left(\mathrm{N} / \mathbf{m m}^{2}\right)\end{array}$ & $\begin{array}{c}\text { Hexagonal } \\
\left(\mathrm{N} / \mathrm{mm}^{2}\right)\end{array}$ & $\begin{array}{c}\text { Triangular } \\
\left(\mathbf{N} / \mathbf{m m}^{2}\right)\end{array}$ \\
\hline B (Blank) & 60 & - & 23.22 & 20.32 & 21.17 \\
\hline $\mathrm{C}$ & 60 & 2 & 26.06 & 22.66 & 23.56 \\
\hline $\mathrm{D}$ & 60 & 5 & 29.93 & 24.48 & 27.12 \\
\hline$E$ & 60 & 7.5 & 34.66 & 26.42 & 32.16 \\
\hline $\mathrm{F}$ & 60 & 10 & 40.12 & 30.42 & 39.19 \\
\hline
\end{tabular}

Table 9: Compressive Strength of sludge-concrete mix pavement tiles after 28 days.

\begin{tabular}{|c|c|c|c|c|c|}
\hline \multirow[b]{2}{*}{ Tiles Code } & \multirow[b]{2}{*}{$\begin{array}{c}\text { Thickness } \\
\text { (mm) }\end{array}$} & \multirow[b]{2}{*}{$\begin{array}{c}\% \text { of } \\
\text { Sludge }\end{array}$} & \multicolumn{3}{|c|}{ Compressive Strength after 7days } \\
\hline & & & $\begin{array}{c}\text { Dumbbell } \\
\left(\mathrm{N} / \mathbf{m m}^{2}\right)\end{array}$ & $\begin{array}{c}\text { Hexagonal } \\
\left(\mathrm{N} / \mathrm{mm}^{2}\right)\end{array}$ & $\begin{array}{c}\text { Triangular } \\
\left(\mathrm{N} / \mathbf{m m}^{2}\right)\end{array}$ \\
\hline B (Blank) & 60 & - & 28.8 & 23.781 & 25.03 \\
\hline $\mathrm{C}$ & 60 & 2 & 31.49 & 29.30 & 30.27 \\
\hline $\mathrm{D}$ & 60 & 5 & 35.27 & 30.47 & 34.41 \\
\hline$E$ & 60 & 7.5 & 41.09 & 32.21 & 38.89 \\
\hline $\mathrm{F}$ & 60 & 10 & 50.03 & 37.23 & 47.58 \\
\hline
\end{tabular}

The results of compressive strength after 7 and 28 days followed the same trend in the samples with the Dumbbell shaped specimen displaying maximum strength and the Hexagonal ones the minimum. Compact, symmetrical shape with lesser surface area could have been one of the vital aspects attributing to the high compressive strength of the Dumbbell shaped tiles. The promising outcome of the experiments was the fact that an increase in the sludge content was directly proportional to the strength of the specimens. On varying the sludge concentration from 0 to $10 \%$, the compressive strength was found to increase irrespective of the thickness or the shape of the tile. Replacing some of the Portland cement with pickling sludge ignites a pozzolanic reaction within the hydrated paste that, via a molecular-level reclamation process and converts into additional Calcium Silica Hydrate (CSH) gel in the sludge cement concrete mix. Moreover, this CSH may facilitate in the cementation process and contribute to the strength of the tiles (Sabir et al., 2001). This is also confirmed by the XRD analysis of the tiles. The XRD analysis of samples B, D and F has been carried out (Figures 2 to 4).The XRD analysis of the tiles revealed that gypsum, dicalcium silicate, tricalcium silicate and $\mathrm{C}-\mathrm{S}-\mathrm{H}$ gel components present in sludge-concrete mix are responsible for gaining the compressive strength of the tiles.

After 28 days, the compressive strength of tiles increases up to $50 \mathrm{MPa}$, which is required in case of heavy traffic area (e.g. Bus terminals, industrial complexes, roads on expansive soils, factory floor, service stations, industrials pavements etc.). A minimum $100 \mathrm{~mm}$ thickness is required on the tiles to achieve a compressive strength of $50 \mathrm{MPa}$ according to IS 15658-2006. However, in this study the requisite strength of tiles for heavy traffic area is achieved at $60 \mathrm{~mm}$. As a result, the production cost of tiles can be reduced. 


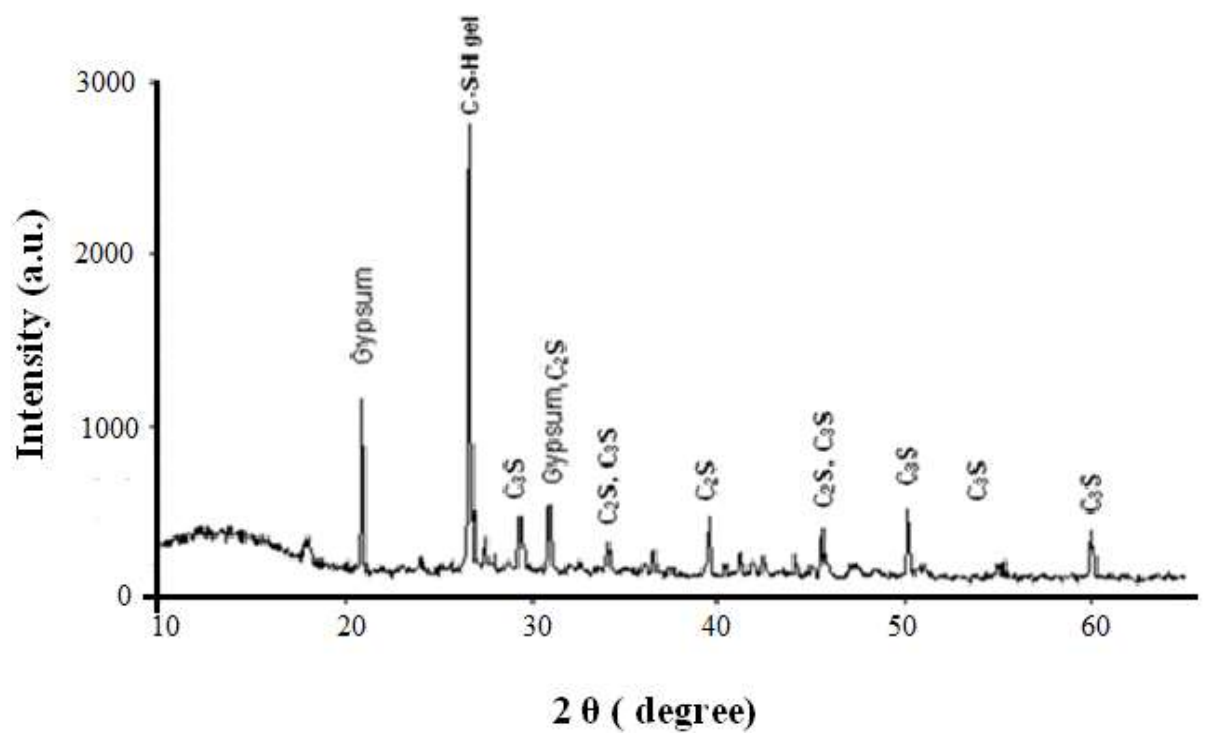

Fig. 2: XRD graph of B tile sample.

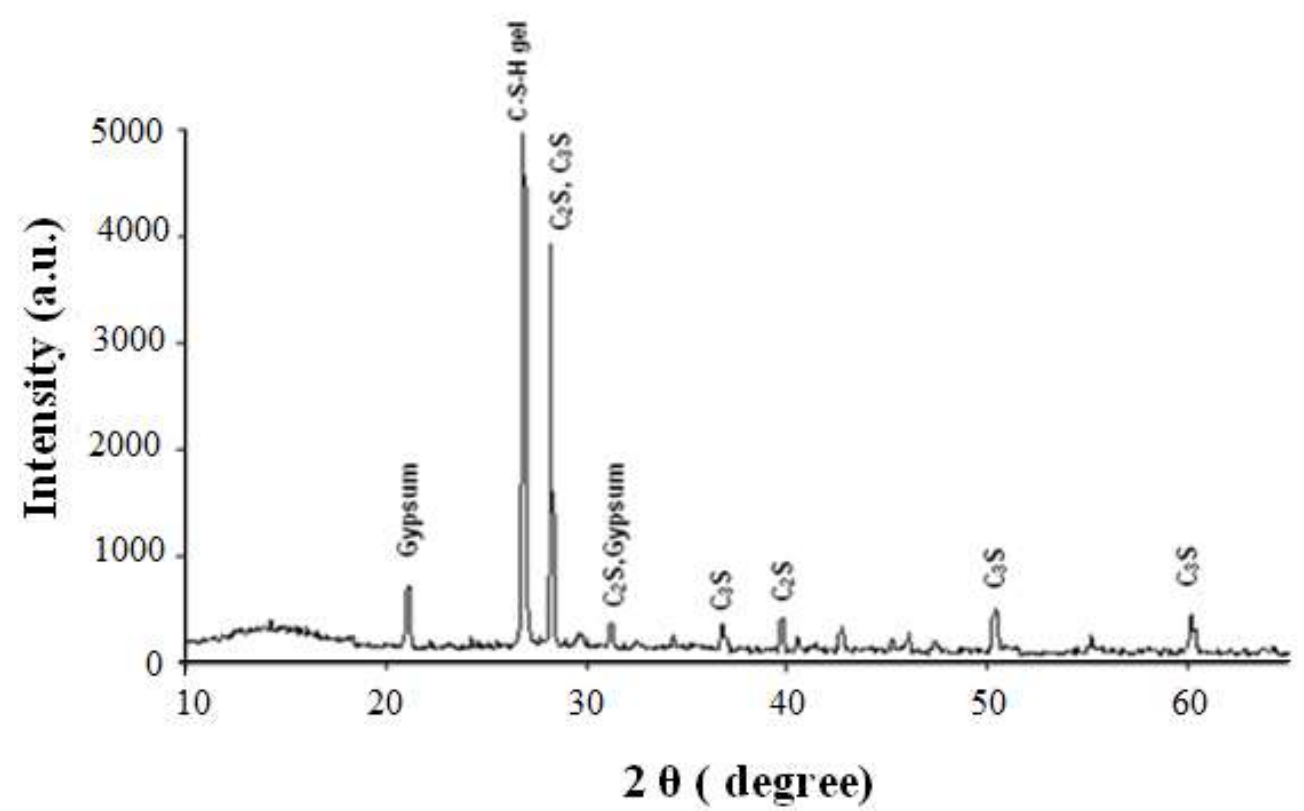

Fig. 3: XRD graph of $\mathrm{D}$ tile sample. 


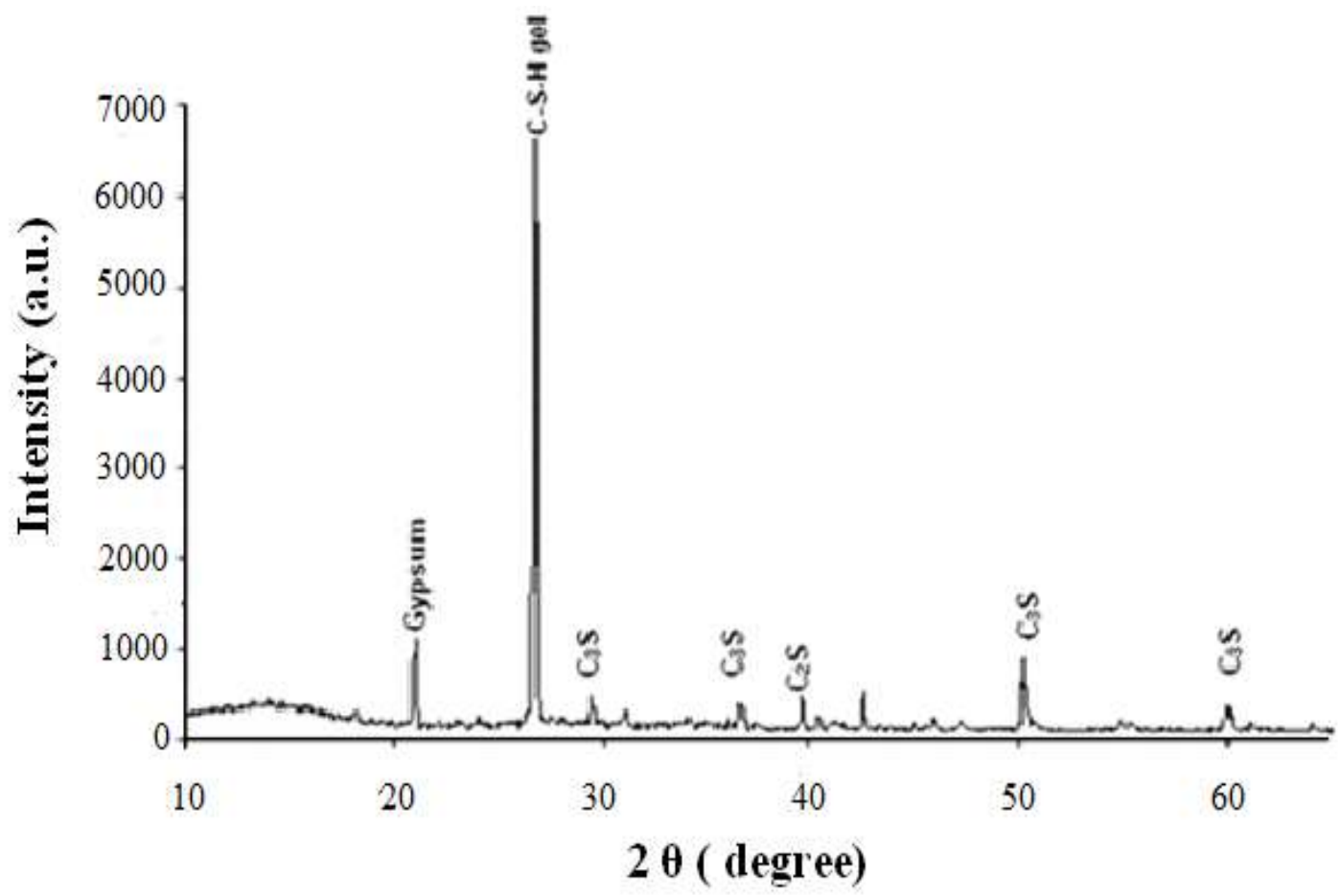

Fig. 4: XRD graph of F tile sample.

\subsection{Cost analysis}

In this study, transportation and labor charges are not accounted because it will be same in cement concrete mix and cement sludge concrete mix. Hence, only materials price has been used for the monetary value analysis study. The cost analysis study is done in two ways:

Case 1: The cost of Blank tile $(60 \mathrm{~mm})$ is compared with sludge cement concrete mix tile (10\% sludge).

Case 2: The cement concrete mix tile of $100 \mathrm{~mm}$ thickness is compared with sludge cement concrete mix tile (10\% sludge) as both are having same compressive strength (50 MPa).

\section{Case 1:}

Cost of cement $=$ Rs $4.8 / \mathrm{kg}$

Cost of sand $=$ Rs $2 / \mathrm{kg}$

Cost of stone grit $=\mathrm{Rs} 2 / \mathrm{kg}$

Cost of per tile for $60 \mathrm{~mm}$ thickness $=$ Rs 9.90

Cost of per tile by using $10 \%$ sludge $=$ Rs. 9.62

Therefore, Rs. 282 can be saved in per 1000 tiles by using $10 \%$ sludge in concrete mix of pavement tiles.

\section{Case 2:}

Cost of per tile for $100 \mathrm{~mm}$ thickness $=$ Rs 16.5

Cost of per tile by using $10 \%$ sludge $=$ Rs. 9.62

Therefore, Rs. 688 can be saved in per 100 tiles by using $10 \%$ sludge in the concrete mixture of pavement tiles in heavy traffic area.

\section{Conclusions}

Pickling sludge is hazardous in nature, so it cannot be disposed of directly at the disposal sites. Leachate of this sludge be may harm both aquatic life and soil. Moreover, disposal of sludge is still a huge problem, as we know that land disposal restrictions are becoming ever increasingly strict, driven by the technical, regulatory and political considerations. The analysis of pickling sludge and cement are homogenous in term of chemical compositionasboth materials contain $\mathrm{CaO}$, $\mathrm{Fe}_{2} \mathrm{O}_{3}, \mathrm{MgO}, \mathrm{SiO}_{2}$ and $\mathrm{Al}_{2} \mathrm{O}_{3}$ as their main components. Therefore, we have tried to replace cement with pickling sludge in cement concrete mix.The investigations have led to the following conclusions: 
a) The compressive strength of the cement-sludge pavement tiles has been found to increase with the addition of sludge as the replacement of cement up to $10 \%$.

b) Negligible concentrations of heavy metals (Fe, $\mathrm{Cr}$ and $\mathrm{Ni}$ ) are present in leachate as per US EPA TCLP test of cement-sludge pavement tiles. Hence, these tiles can be safely used on the footpath.

c) This will not only solve the disposal problem, but also decrease the manufacturing cost Rs. 688 per 100 tiles by using $10 \%$ sludge in concrete mix of pavement tiles in heavy traffic area.

The results are checked and are found to be good as compared to other observations. Tiles were also tested in field and found to be compartavely same in strength as of normal tiles.

\section{Further scope of the work}

The percentage of sludge can be increased in the concrete-sludge mix above $10 \%$ until it retard the properties of sludge.

\section{References}

[1] A. Agrawal and K. K. Sahu KK, "Value addition to sulfate waste pickle liquor of steel industry using hydro metallurgical processes," Metallurgical and Materials Transactions B, vol. 40, pp. 877-885, 2009.

[2] A. A. Baba, F. A. Adekola, O. S. Awobode, B. R. Adekunle, S. Pradhan and A. Biswal, "Analysis of heavy metals from spent pickling liquor of sulfuric acid," International Journal of Chemical, vol. 21, no. 4, pp. 231-240, 2011.

[3] Bing Tang, Wen Su, Jing Wang, Fenglian Fu, Guojun Yu and Jianyin Zhang, "Minimizing the creation of spent pickling liquors in a pickling process with high-concentration hydrochloric acid solutions: Mechanism and evaluation method," Journal of Environmental Management, vol. 98, pp. 147-154, 2012.

[4] Bralla James, Handbook of Manufacturing Processes: How product, components and materials are made. New Delhi, 2007.

[5] Devi Anuradha, Singhal Anupam, Gupta Rajiv and Panzade Prasad, "A Study on treatment methods of spent pickling liquor generated by pickling process of mild steel," Clean Technology Environmental Policy, vol. 16, pp. 1515-1527, 2014.

[6] Z. Z. Ismail and E. A. AL-Hashmi, "Reuse of waste iron as a partial replacement of sand in concrete," Waste Management vol. 28, pp. 2048-2053, 2008.

[7] M. Ito, R. Tachibana, K. Fukushima, Y. Seino, A. Yamamoto and Y. Kawabata, "Characteristics and production: mechanism of sulfuric acid and nitric-hydrofluoric acid pickling sludge produced in manufacture of stainless steel," Journal of Chemical Engineering Japan, vol. 31, pp. 589-595, 1998.

[8] Regel-Rosocka M, "A review on methods of regeneration of spent pickling solutions from steel processing," Journal of Hazardous Material, vol. 177, no. 1, pp. 57-69, 2010.

[9] F. Rogener, M. Sartor, A. Ban, D. Bucholoh and T. Reichard, "Metal recovery from spent stainless steel pickling solution," Resource Conservation Recycle, vol. 60, pp. 72-77, 2012.

[10] B. B. Sabir, S. Wild and J. Bai, "Metakaolin and calcined clays as pozzolans for concrete: A review," Cement and concrete composites, vol. 23, pp. 441-454, 2001.

[11] Singhal Anupam, Prakash Satya and Tewari V.K., "Trials on sludge of lime treated spent liquor of pickling unit for use in the cement concrete and its leaching characteristics," Building and Environment, vol. 42, pp. 196-202, 2007.

[12] Singhal Anupam, Prakash Satya and Tewari V.K. "Characterization of stainless steel pickling bath sludge and its solidification/stabilization," Building and Environment, vol. 43, pp. 1010-1015, 2008.

[13] J. L. Galvez, J. Dufour, C. Negro and F. Lopez-Mateos, "Fluoride speciation in stainless steel pickling liquor," Iron \& Steel Institute of Japan, vol. 46, no. 2, pp. 281-286, 2006.

[14] A. K. Minocha, N. Jain and C. L. Verma, "Effect of inorganic materials on the solidification of heavy metals sludge," Cement Concrete Resource, vol. 33, pp. 1695-1701, 2003.

[15] R. Vijay and T. A. Sihorwala, "Identification and leaching characteristics of sludge generated from metal pickling and electroplating industries by toxicity characteristics leaching procedure (TCLP)," Environmental Monitoring and Assessment, vol. 84, pp. 193-202, 2003.

[16] L. K. Wang, Waste treatment in the metal manufacturing, forming, coating and finishing industries. Waste Treatment Bulletin, New York, 2009. 